\title{
Keamanan Negara dalam Kegiatan Antariksa Nasional: Perspektif Realis Ofensif
}

\author{
Totok Sudjatmiko \\ Pusat Pengkajian dan Informasi Kedirgantaraan \\ Lembaga Penerbangan dan Antariksa Nasional
}

\begin{abstract}
ABSTRAK
Antariksa adalah kawasan yang dapat dikolaborasikan dengan penggunaan hard dan soft power dalam konteks keamanan negara. Perkembangan dalam satu kawasan ini akan dapat berdampak langsung pada kawasan lain. Nilai strategis tersebut membuat keamanan negara dalam kegiatan antariksa saat ini menjadi penting dalam kebijakan luar negeri suatu negara. Sehingga kebutuhan akan rasa aman bangsa dan negara dari gangguan dan ancaman pihak lain dapat terpenuhi. Untuk itu keamanan negara terkait kegiatan antariksa harus menempati prioritas utama dalam kebijakan luar negeri. Dimana kemudian Indonesia menuangkan aspek keamanan itu dalam Pasal 1 Ayat 12 dan Pasal 8 UU No. 21 Tahun 2013 Tentang Keantariksaan. Adapun yang menjadi permasalahan penelitian adalah apakah keamanan Indonesia dari antariksa telah tercermin dalam Pasal 1 ayat 12 dan Pasal 8 UndangUndang No. 21 Tahun 2013 Tentang Keantariksaan yang memuat materi tentang keamanan apabila ditinjau dari kebijakan luar negeri realis ofensif.
\end{abstract}

Kata-Kata Kunci: Kebijakan Luar Negeri, Kegiatan Antariksa, Keamanan.

Space is an area that has flexibility to be collaborated with both soft and power in term of national security. This strategic postion of space makes it has influencial strategic value over state's security. State security in space activity is becoming important in a state foreign policy. Thus the need for security of the nation and the state of disruption and threat of another party can be met. To the state security related space activities should occupy top priority in foreign policy. Where then Indonesia decant the security aspect in Space Act, Article 1 Section 12 and Article 8 of Law No.21 Year 2013. As for the problem of research is what the Indonesian security from space has been already reflected in Article 1 Section 12 and Article 8 of Law No. 21 Year 2013 which containing material about security if reviewed from the foreign policy realists offensive.

Keywords: Foreign Policy, Space Activity, Security. 
Pada saat ini dan juga di masa depan nanti lingkungan strategis diwarnai dengan tiga tren yang sangat signifikan, yaitu antariksa akan semakin padat, sehingga diperebutkan, dan oleh sebab itu menjadi hal yang kompetitif. Kondisi tersebut akan terus bergulir dan tentu saja akan mendorong negara-negara untuk melakukan upaya-upaya meningkatkan kapasitas dalam hal kegiatan antariksanya. Menjadi suatu hal yang wajar pada saat disadari bahwa peran antariksa dalam kehidupan manusia saat ini maupun dimasa datang sangatlah besar. Hampir seluruh aspek kehidupan akan dapat didukung penuh oleh kegiatan antariksa. Secara khusus dapat ditemui pada aspek keamanan. Apabila berbicara aspek keamanan maka tidak akan pernah atau dapat dikatakan satu hal yang tidak boleh luput adalah keamanan nasional. Keamanan nasional merupakan urat nadi kebutuhan hidup bagi suatu bangsa. Kebutuhan akan rasa aman dalam kehidupan berbangsa dan khususnya bernegara pada saat melihat lingkungan strategis keberadaan kita ditengah-tengah masyarakat internasional.

Oleh sebab itu dalam memenuhi kebutuhan keamanan nasional saat ini dan di masa depan akan sangat tergantung kepada kemampuan suatu negara dalam kegiatan antariksanya. Antariksa menjadi hal yang kritis bagi keamanan suatu negara. Hal ini disebabkan karena antariksa merupakan satu-satunya kawasan fisik yang memiliki kemampuan dalam mencakup seluruh permukaan bumi. Antariksa bahkan telah menjadi suatu sumber dalam mendapatkan akses kemampuan militer yang mumpuni yaitu kemampuan tingkat peralatan yang cerdas dan mampu mengendalikan serta mengirimkan senjata. Tantangan terhadap peningkatan teknologi persenjataan sangat terbuka luas ketika berada di kawasan antariksa, seperti misil balistik dan satelit militer yang sangat memiliki kekuatan luar biasa dan dapat disebarkan penggunaannnya oleh negara-negara.

Terkait dengan lingkungan strategis kondisi dunia yang diwarnai 3 tren yaitu antariksa semakin padat, diperebutkan dan digunakan untuk kompetisi tersebut, maka pertanyaan penelitiannya adalah, apakah keamanan Indonesia dari antariksa telah tercermin dalam Pasal 1 ayat 12 dan Pasal 8 Undang-Undang No. 21 Tahun 2013 Tentang Keantariksaan yang memuat materi tentang keamanan apabila ditinjau dari kebijakan luar negeri realis ofensif.

Kemampuan mencapai antariksa memberikan akses pada suatu negara untuk mengembangkan persenjataan, antara lain adalah wahana peluncur antariksa yang berupa misil balistik yang sangat kuat dengan kemampuan jelajah antar benua dan mampu dimuati hulu ledak tinggi dan penggunaan satelit militer yang digunakan untuk memata-matai lawan. Sehingga meskipun digunakan di masa damai, tetapi daya rusak 
senjata yang menggunakan teknologi antariksa akan mampu menimbulkan kerusakan yang luar biasa pada target musuh yang ada.

Dari sudut pandang hubungan internasional dalam kondisi dunia yang diwarnai ke-3 tren tersebut diatas maka kepemilikian atau mendapatkan power sebesar mungkin merupakan langkah yang sangat strategis. Untuk itulah pemikiran terhadap perlunya kemampuan keantariksaan yang harus dimiliki yang ditujukan untuk memenuhi keamanan nasional sangat krusial dan pendekatan realis ofensif melihat itu sebagai sebuah kepentingan mendasar. Karena pada hakekatnya keagresifan suatu negara seringkali didorong oleh kondisi baik eksternal maupun internal yang kondusif terhadap tumbuhnya sikap agresif negara dalam mempersenjatai dirinya. Sikap negara tersebut merupakan pencerminan tanggung jawab dan tugas negara sejalan dengan pendapat Adam Smith yang menyatakan bahwa tugas pertama dari negara berdaulat adalah melindungi masyarakatnya dari kekerasan dan invasi dari masyarakat berdaulat lainnya, dan hal itu dapat dilakukan hanya dengan kekuatan militer. Bahkan Piagam PBB pun melarang penggunaan kekuatan yang agresif, meskipun peluang besar masih diberikan untuk kepentingan membela diri dan menggunakan kekuatan bersenjata melalui sanksi dewan keamanan. Demikian juga dengan kegiatan antariksa yang diarahkan untuk kepentingan keamanan, dimana keamanan dalam hal ini adalah terkait dengan efek dari kegiatan antariksa yang mengandung muatan militer meskipun dalam kondisi damai tetapi tetap dapat digunakan. Penggunaan antariksa dalam aspek keamanan nasional secara sederhana juga tercermin dalam Space Treaty yang melarang penggunaan kekuatan agresif. Tetapi pelarangan penggunaan kekuatan agresif ini tidak dapat dibaca dalam arti benar-benar menghalangi penggunaannya di antariksa. Hal ini dalam prakteknya pun dilakukan oleh negara-negara dengan pengembangan kekuatan militer berbasis teknologi antariksa dalam postur sikap defensif. Sikap defensif kemudian dimaknakan sebagai perilaku awal yang kemudian dengan kondisi yang kondusif dari eksternal maupun internal mendorong negara untuk mengembangkan sikap ofensif.

Kebijakan luar negeri suatu negara pada konteks pemenuhan keamanan nasional di era antariksa juga dengan berdasar kepada kondisi eksternal dan internal yang lebih kompleks pada aplikasinya tetapi lebih terlihat sederhana dari sisi logika. Artinya adalah dengan menguasai antariksa maka satu negara dalam kebijakan luar negerinya lebih mudah memenuhi kebutuhan keamanan nasional khususnya keamanan fisik dari gangguan dan ancaman negara lain. Selanjutnya, keamanan fisik dari gangguan dan ancaman itu akan tercermin atau dirumuskan ke dalam kebijakan luar negeri suatu negara. Dalam konteks itu pula Indonesia sebagai negara yang berdaulat dan memiliki lingkungan geopolitik dan geostrategi yang dinamis dengan potensi ancaman tinggi 
perlu untuk memiliki kemampuan antariksa bagi kegiatan keamanan nasional. Keamanan di bidang keantariksaan Indo-nesia dapat ditemui di dalam perangkat peraturan perundang-undangan yang mengatur kegiatan antariksa dalam UU No. 21 Tahun 2013 tentang Keantariksaan, khususnya terkait definisi keamanan diatur dalam pasal 1 ayat 12, sedangkan persepsi ancaman atau potensi ancaman diatur pasal 8.

Kebijakan Luar Negeri yang bersifat realis ofensif ini dicetuskan oleh Mearsheimer. Karakteristik dari realis ofensif yang mewarnai kebijakan luar negari ini adalah mendapatkan power sebesar mungkin adalah langkah strategis terutama bila keadaan memungkinkan untuk mendapatkan hegemoni. Sedangkan tujuan dari mendapatkan power sebesar mungkin ini adalah bukan untuk menaklukkan atau melakukan dominasi tetapi bahwa memiliki kekuasaan yang melimpah itu adalah satu cara yang paling baik untuk menjamin pertahanan diri dan kelangsungan hidup. Sehingga apabila negara tersebut harus berhadapan dengan negara lain atau bahkan negara lawannya maka dengan keunggulan militer akan dapat mendorong rasa aman. Karena kondisi dunia yang anarki maka pandangan terhadap peningkatan dan pengembangan kekuatan yang relatif haruslah terus ditingkatkan meskipun ada ancaman ataupun tidak.

Kemudian yang dimaksud dengan dunia dalam kondisi anarki dalam hubungan internasional adalah merujuk kepada fakta bahwa tidak ada badan diatas negara yang berdaulat didalam masyarakat internasional. Untuk itu maka tidak ada harapan untuk menegakkan hukum internasional atau menegakkan kode etik moral universal yang memandu tindakan dari para pemimpin. Selanjutnya, selama struktur sistem internasional tetap anarki maka negara harus melanjutkan upaya menjamin pertahanan dan kekuatan mereka sendiri, atau ancaman itu akan terus berlanjut sebagai hasil dari suatu interaksi internasional.

Secara tegas disampaikan oleh Frankel, bahwa bagi realisme ofensif, bukanlah sifat negara-negara itu yang agresif, tetapi ciri-ciri yang sistemik dari sistem yang memaksa negara-negara terlepas dari motifnya untuk melakukan strategi ofensif dalam mengejar keamanan mereka. Sistem yang terbentuk di dunia internasional berupa struktur politik internasional merupakan kunci dalam memahami keadaan dan secara eksklusif adalah perilaku negara. Struktur politik internasional oleh Mearsheimer diasumsikan dalam 5 asumsi utama, yaitu : Pertama, bahwa politik internasional itu diaplikasikan pada kondisi dunia yang anarkis, yang berarti bahwa tidak ada pemerintah dari pemerintahan yang dapat menegakkan aturan dan memberikan hukuman kepada pelakunya. 
Kedua, tidak ada negara yang dapat benar-benar yakin terhadap niat dari masing-masing atau memastikan apakah negara-negara lain tidak akan menggunakan kekuatan bersenjata terhadap mereka. Selain itu negara juga kurang mendapat informasi yang tepat atas niat masingmasing negara, apakah niat itu baik atau dengan cepat berubah menjadi destruktif atau sebaliknya.

Ketiga, kelangsungan hidup merupakan motivasi utama dari seluruh negara di dalam sistem internasional. Kelangsungan hidup harus berada dalam prioritas utama sejak negara tersebut berdiri atau otonom dan itu menjadi prasyarat bagi semua tujuan yang ingin dicapai dalam negara tersebut.

Keempat, negara adalah entitas rasional dan mereka berpikir secara strategis tentang situasi eksternal dan pilihan strategi yang dapat digunakan untuk memaksimalkan tujuan dasar negara itu untuk hidup.

Dan yang terakhir adalah, bahwa setiap negara akan selalu memiliki beberapa kemampuan militer yang mampu digunakan untuk melakukan penyerangan dan memungkinkan untuk saling menghancurkan.

Dengan lima asumsi tersebut maka Mearshemeir berupaya menekankan bahwa pada konteks hegemoni yang ingin dicapai suatu negara dimaknakan sebagai upaya suatu negara yang tidak selalu berada pada kondisi fisik menguasai negara lain. Melainkan dengan kemampuannya yang powerful maka negara tersebut akan mendominasi sistem internasional, dimana negara-negara akan tunduk terhadap sistem tersebut, hal itu berlaku baik pada tataran global maupun regional. Kemudian Mearshemeir menjelaskan bahwa hubungan antara kekuatan-kekuatan besar dunia yang ada dalam sistem negara modern memiliki kecenderungan penuh konflik. Hal ini dikarenakan kondisi dunia yang diwarnai dengan tingkat persaingan yang cukup tinggi. Sejalan dengan tingkat persaingan yang cukup tinggi itulah, maka kekuatan militer kemudian menjadi hal terpenting ketika menganalisa politik dunia karena hal tersebut adalah rasio tertinggi dari politik internasional.

Dalam kondisi dunia yang selalu berisikan keadaan persaingan tersebut maka akan selalu ada negara yang revisionis dan yang ingin menjadi hegemon serta terus berusaha memperbaiki posisinya di dunia internasional. Maka secara sederhana dapat dikatakan bahwa pendekatan realis ofensif ini meletakkan lingkup perhatiannya kepada hal-hal yang berkaitan sebagai berikut, bahwa keamanan adalah suatu hal yang langka, sehingga menyerang atau bertahan tidak dapat dibedakan, kemudian semua itu didukung oleh teknologi atau geografi yang kondusif terhadap penyerangan. 


\section{Definisi Keamanan yang terkandung pada Pasal 1 Ayat 12 Undang-Undang No. 21 Tahun 2013 Tentang Keantariksaan}

Sebagai pintu masuk dalam memahami keamanan khususnya dari sisi politik adalah dengan melihat kepada makna keamanan. Keamanan saat ini dipandang sebagai sebuah nilai politik. Kemudian dalam pemahaman konsepnya memiliki beberapa pengertian, dan salah satunya disampaikan oleh H.G. Brauch dari Wolfers. Menurut H.G.Brauch keamanan dibagi dalam dua arti, yaitu: pertama, keamanan dalam arti obyektif, yang dimaksud adalah mengukur adanya ancaman terhadap nilai-nilai yang dimiliki. Kedua, keamanan dalam arti subyektif, yang dimaksud adalah adanya ketakutan bahwa akan terjadi penyerangan terhadap nilai-nilai tersebut.

Kemudian jika dikaitkan dengan keamanan antariksa, maka dapat dilihat pada pemahaman dari dua negara besar misalnya, Amerika dan China. Amerika melalui departemen pertahanannya menunjukkan hal yang sangat bernuansa kompetitif. Pemahaman tersebut menekankan pada pandangan bahwa keamanan antariksa secara strategis merupakan suatu kawasan yang padat, diperebutkan dan bersifat kompetitif. Selanjutnya bila dilihat kepada pandangan China, keamanan antariksa menduduki posisi sangat strategis, hal ini karena bagi China secara strategis menganggap bahwa antariksa adalah sebagai medan pertempuran yang krusial pada perang di masa depan.

Melihat kepada pasal 1 Ayat 12 Tahun 2013 Tentang Keantariksaan, Keamanan dimaknakan sebagai segala upaya dan komitmen secara internasional bagi setiap Penyelenggara Keantariksaan untuk memelihara dan/atau menjamin pemanfaatan Antariksa dan bendabenda langit lainnya untuk maksud-maksud damai dan tidak menimbulkan kerusakan bagi lingkungan bumi dan Antariksa melalui keterpaduan pemanfaatan sumber daya manusia, fasilitas, dan prosedur.

Dua hal yang sangat bertolak belakang apabila dilihat dari makna keamanan antariksa. Di satu sisi, pada negara-negara maju memandang antariksa sangat potensial terhadap kepentingan keamanan bangsa dan negara mereka. Di sisi lain bersifat sangat lunak, dengan mengesampingkan kuatnya kepentingan keamanan bangsa dan negara. 


\section{Persepsi Ancaman yang terkandung pada Pasal 8 Undang-Undang No. 21 Tahun 2013 Tentang Keantariksaan}

Persepsi ancaman bisa dipahami dengan melihat kepada sebuah negara mengidentifikasi suatu obyek atau fenomena sebagai suatu bahaya bagi keamanannya, maka negara tersebut menganggapnya sebagai sebuah ancaman. Kemudian dalam kerangka mengantisipasi dan menghadapi obyek atau fenomena yang dianggap sebagai sebuah ancaman tersebut maka suatu negara akan mengedepankan kebijakan terkait cara-cara menghentikan, menghindari, dan membalas ancaman yang diidentifikasi tersebut. Di dalam literatur Hubungan Internasional ancaman ini didefinisikan sebagai situasi dimana satu agen atau kelompok memiliki kemampuan atau keinginan untuk menimbulkan konsekuensi negatif terhadap agen atau kelompok yang lain.

Kemudian pada konteks ancaman ini H.G.Brauch juga menyampaikan dari Ullman, bahwa ancaman terhadap keamanan nasional adalah sebagai suatu tindakan atau urutan peristiwa, yaitu: pertama, secara drastis mengancam dan selama rentang waktu yang relatif singkat menurunkan kualitas hidup bagi penduduk suatu negara. Kedua, secara signifikan mengancam dalam mempersempit berbagai pilihan kebijakan yang tersedia bagi pemerintah suatu negara atau entitas non-negara dalam satu negara. Pada konteks ancaman ini, Indonesia juga tidak luput akan mengalami hal serupa sehingga akan melemahkan keamanan dan pertahanan Indonesia sebagai satu entitas negara. Ancaman yang dapat menurunkan kualitas hidup dan mempersempit pilihan kebijakan bagi pemerintah suatu negara tentu akan sangat melemahkan keberadaan negara tersebut.

Sehingga menjadi suatu konsekuensi logis bagi suatu negara untuk mengembangkan suatu daya tangkal dengan mengaplikasikan teknologi yang mumpuni. Teknologi itu adalah teknologi antariksa, dimana kemampuan yang dimiliki sangatlah luas dalam melingkupi keamanan dan pertahanan suatu negara. Menjadi logis bagi suatu negara untuk mengembangkan teknologi antariksa semaksimal mungkin ketika harus menangkal segala ancaman yang datang. Khususnya Indonesia, mengingat keunikan Indonesia yang memiliki karakteristik yang demikian strategis, karena wilayah laut Indonesia adalah "the largest body of water in the world" dan ditambah dengan kondisi perbatasan kepulauan Indonesia dengan berbagai negara yang meliputi wilayah luarnya (perbatasan wilayah luar Indonesia terkait dengan 10 negara lainnya), perlu diikat dengan satu untaian "life-line" (garis hidup) yang solid dan terpadu dengan wilayah daratnya yang demikian luas. 
Tetapi apabila melihat kepada muatan Pasal 8 UU No. 21 Tahun 2013 Tentang Keantariksaan adalah setiap kegiatan keantariksaan dilarang: (a) Menempatkan, mengorbitkan, atau mengoperasikan senjata nuklir dan senjata perusak massal lainnya di Antariksa; (b) Melakukan uji senjata nuklir dan senjata perusak massal lainnya di Antariksa; (c) Menggunakan bulan dan Benda Antariksa alam lainnya untuk tujuan militer atau tujuan lain yang mencelakakan umat manusia; (d) Melakukan kegiatan yang dapat mengancam Keamanan dan Keselamatan Penyelenggaraan Keantariksaan termasuk keamanan Benda Antariksa, perseorangan, dan kepentingan umum; atau (e) Melakukan kegiatan yang dapat mengakibatkan pencemaran dan/atau kerusakan lingkungan hidup bumi dan Antariksa serta membahayakan kegiatan Keantariksaan termasuk penghancuran Benda Antariksa.

Maka hal ini menjadi kontraproduktif, karena muatannya mengisyaratkan tingkat kemajuan teknologi antariksa yang telah dimiliki oleh negara-negara maju dan sekaligus menjadi ancaman bagi negara lain. Sehingga ancaman itu selain memang menjadi ancaman dalam arti sesungguhnya tetapi di sisi lain telah menjadi halangan bagi negara atau pihak lain yang ingin mengembangkan, termasuk Indonesia.

\section{Distribusi Kapabilitas di dalam Struktur Internasional}

Dalam memahami dan menjelaskan struktur internasional terlebih dahulu perlu dilihat tatanan internasional. Tatanan internasional ini memiliki fokus perhatian kepada dua hal penting, yaitu struktur yang berupa distribusi power dan fungsi yang berupa penyeimbang atau dominasi. Oleh karena itu tatanan internasional merupakan sebuah konsekuensi dari lingkungan internasional yang berupaya untuk memenuhi kebutuhannya sendiri dan harus berjuang untuk bertahan hidup. Tatanan internasional yang sudah ada juga merupakan manifestasi dari distribusi power. Artinya, jumlah negara yang muncul sebagai negara yang terkuat akan sangat berpotensi membentuk sistem yang berlaku dalam tatanan internasional.

\section{Sistem Bipolar}

Sistem ini terbentuk dengan kemunculan dua kekuatan yang teraktualisasi di dalam dua negara dan kemudian lebih lanjut membentuk dua kutub negara. Satu kutub merupakan satu negara atau sekumpulan negara dimana satu negara yang memimpin blok tersebut dan kemudian beberapa negara yang bersekutu dengan negara pemimpin blok. Periode terjadinya sistem bipolar ini yaitu pada tahun 1945 sampai dengan 1990. Tatanan dalam sistem ini oleh pemikiran banyak para sejarawan dan para pemikir politik dianggap sebagai suatu 
sistem yang sangat aman dan stabil, sehingga tidak rentan terhadap perubahan dan memiliki kemungkinan yang sedikit untuk terjadinya pertempuran yang mematikan, terkait keanggotaan akan selalu sama dalam satu periode. Karena keanggotaan yang sama tersebut maka kekuatan masing-masing pihak yang berpotensi melakukan agresi akan dikoreksi secara langsung oleh pihak yang lain.

\section{Sistem Multipolar dan Unipolar}

Dalam sistem ini sebaran kekuasaan dan kekuatan didistribusikan setidaknya pada tiga negara, tetapi pada kenyataannya kekuatan biasanya tersebar pada 4, 5, 6 atau bahkan lebih. Pada sisi sejarah dapat dilihat sistem ini berlaku sebagai sistem internasional pada periode 1648-1945 dengan pelaku utama adalah Austria, Prussia, Italia, Perancis, Rusia dan Inggris. Setelah periode tersebut berlaku kemudian sistem bipolar dan seiring waktu semenjak kejatuhan Uni Soviet pada tahun 1992 Amerika memegang kendali utama pelaku sistem internasional sehingga dunia internasional memasuki sistem yang sangat rapuh yaitu unipolar.

Kerapuhan sistem ini karena kekuasaan dan kekuatan terpusat pada satu pihak yaitu Amerika, sedangkan seiring waktu setiap negara akan mengejar kepentingan nasionalnya dengan memperkuat pertahanan dan keamanan nasional, dan pada gilirannya akan mengancam dominasi Amerika. Keadaan ini berkembang hingga sekarang dan kemudian kekuatan terpecah dalam banyak kutub dan menjadi multipolar. Tetapi kecenderungan multipolar yang ditandai dengan kebijakan-kebijakan unilateral Amerika ini pun dilihat telah bergeser secara signifikan. Hal ini ditengarai oleh Yan Xuetong, bahwa Amerika telah kehilangan statusnya sebagai superpower yang terkuat sejak berakhirnya perang dingin. Dinamika kekuatan superpower internasional saat ini telah masuk era transisi dari sistem unipolar dengan Amerika sebagai pusatnya ke sistem bipolar dengan China yang menguasai kutub yang lain.

\section{Unipolarisme Kegiatan Antariksa Dalam Keamanan Nasional}

Unipolaritas kegiatan antariksa sulit dilepaskan dari kepentingan nasional satu negara, baik itu untuk kepentingan sipil maupun militer. Khususnya negara kuat seperti Amerika.Amerika diketahui sangat mendominasi kegiatan antariksa, bahkan Amerika adalah satu negara yang meletakkan kekuatan nasionalnya dengan berbasiskan kekuatan antariksa. Dalam visi 2020 yang dimiliki Amerika sangat jelas terlihat bahwa Amerika sangat menginginkan dominasi yang kuat. Pada visi 2020 tersebut ditetapkan dua tema yang menjadi prinsip dominasi, yaitu: pertama, mendominasi dimensi antariksa dalam operasi militer 
untuk melindungi kepentingan Amerika dan Investasinya dan yang kedua mengintegrasikan kekuatan antariksa kedalam kemampuan berperang yang mampu melintasi seluruh spektrum konflik.

Dari dua tema prinsip dalam visi Amerika tersebut mewajibkan beberapa hal, meliputi: (1) Pengendalian Antariksa; (2) Keterlibatan secara global (Kepekaan kondisi situasional dunia, pertahanan terhadap misil balistik, dan kemampuan untuk menahan resiko dari Antariksa terhadap beberapa target bernilai tinggi); (3) Integrasi kekuatan secara penuh (Integrasi kekuatan Antariksa dengan kekuatan darat, laut, dan udara, dimana para prajurit mampu mengambil keuntungan dari kemampuan Antariksa sebagai satu bagian khusus yang tidak terpisahkan, dan mengkombinasikan dengan menggabungkan peperangan darat, laut dan udara)

Kemudian dalam kegiatan antariksa untuk kepentingan sipil pun Amerika jelas mendominasi, seperti dominasi yang dilakukan oleh pesawat antariksa NASA dan kegiatan Stasiun Antariksa Internasional. Selain itu di dalam pengoperasian satelit pun didominasi Amerika. Pada konteks ini banyak satelit komersil yang dapat digunakan untuk tujuan militer dan sipil, termasuk penggunaan satelit dalam GPS yang didesain dan dikendalikan oleh Departemen Pertahanan Amerika. Sistem ini dalam waktu perang digunakan untuk mengindentifikasikan target dan menyediakan pemandu senjata untuk menembak target dengan akurasi yang tepat. Kemudian wakil menteri pertahanan Amerika Robert Work mengumumkan dalam simposium konferensi tahunan GEOINT tahun 2015, bahwa Pentagon akan membangun pusat komando gabungan yang mengkoodinasikan respon terhadap serangan aset militer antariksa Amerika. Pusat komando tersebut dalam waktu enam bulan akan segera berfungsi penuh dan pusat itu digunakan untuk mempertahankan Amerika sebagai kekuatan global.

Robert Work secara terbuka juga mengakui bahwa langkah tersebut dilakukan sebagai upaya Pentagon dalam mempertahankan dominasi Amerika dan menghadapi dugaan serangan dari China dan Rusia. Fungsi yang paling menonjol dari pusat ini adalah dimaksudkan untuk mendeteksi satelit militer dan lintasannya pada saat yang sama sehingga intelijen AS dan militer dapat bekerja sama untuk menciptakan pertahanan yang terbaik terutama terhadap serangan pada sistem satelit. Pertahanan tersebut adalah dengan mengembangkan taktik, teknik, prosedur, aturan yang memungkinkan Amerika untuk melawan dan melindungi diri ketika mendapatkan serangan. Karena kenyataan terburuk yang harus dihadapi adalah apabila lawan mampu mengambil alih atau merebut antariksa dari dominasi Amerika, dimana hal itu akan melemahkan kemampuan Amerika khususnya dalam memproyeksikan kekuatan yang menentukan. 


\section{Pendekatan Realis Offensif dalam melihat Kebijakan Luar Negeri Keantariksaan Indonesia di bidang keamanan yang tertuang dalam UU RI No. 21 Tahun 2013 Tentang Keantariksaan}

Analisis ini diawali dengan pendapat dari Thucydides, yang mengatakan bahwa di dalam sistem internasional, negara kuat melakukan apa yang mereka dapat lakukan, dan pihak yang lemah akan menderita atas apa yang tidak dapat mereka lakukan. Pada konteks ini maka nampak bahwa negara kuat akan selalu dapat dengan bebas melakukan apa yang mereka kehendaki. Termasuk didalamnya kepemilikan, penguasaan dan penggunaan teknologi antariksa. Mengapa demikian, karena Antariksa pada abad 21 telah menjadi hal yang utama dalam menentukan suatu sistem persenjataan yang mampu bergerak bebas dan memiliki ketepatan dengan sifat yang sulit dideteksi atau bekerja secara diamdiam (stealth). Sehingga sangat mendukung dalam pengendalian dan penguasaan pada kegiatan pengumpulan data dan informasi intelijen.

Strategi untuk pencegahan di bidang keamanan dalam abad 21 ini sangat tergantung kepada penggelaran kemampuan di antariksa. Antariksa menjadi bagian yang sangat esensial sebagai sebuah keseluruhan operasi strategis, dan keseluruhan operasi strategis itu akan menjadi suatu strategi yang utuh. Hal itu kemudian dijelaskan oleh Daoed Joesoef, bahwa strategi merupakan keseluruhan operasi intelektual dan fisik yang diniscayakan untuk menanggapi, menyiapkan, dan mengendalikan setiap kegiatan kolektif di tengah-tengah konflik.

Kekuatan antariksa sebagai bagian dari strategi yang utuh memiliki pemahaman bahwa kekuatan antariksa telah memperluas wilayah atau matra dalam konfigurasi geografi tradisional. Adapun wujud konfigurasi geografi tradisional adalah horizontal diatas bumi yaitu berupa daratan dan laut yang kemudian berkembang dengan arah vertikal yang memanjang dari wilayah udara sampai ke antariksa. Sehingga antariksa sebagai kekuatan memiliki keniscayaan untuk diaplikasikan dan ditingkatkan penggunaannya sebagai instrumen untuk meraih, menjaga dan memelihara keamanan nasional.

Memahami keamanan negara atau keamanan nasional dalam perspektif realis ofensif ini dapat dimulai dengan mengetahui definisi ofensif tersebut. Operasi ofensif adalah suatu tindakan dimana suatu negara menggunakan kekuatan untuk menyerang negara lain secara militer atau menyerang aset non militer untuk menaklukan wilayahnya atau memaksa untuk patuh dengan perintah (memaksakan kehendaknya kepada negara lain). Penggunaan kekuatan untuk menyerang negara lain itu dapat diartikan sebagai tindakan yang dalam pemahaman keamanan nasional pada konteks modern adalah suatu persyaratan 
dasar untuk menjaga kelangsungan hidup suatu negara (state) dengan mempergunakan instrumen ekonomi, diplomasi, kekuatan militer, dan kekuatan politik. Kelangsungan hidup ini merupakan esensi dari ruh kehidupan negara yang harus diwujudkan dan dipertahankan bagaimanapun caranya. Seluruh instrumen yang terhimpun tersebut selanjutnya menjadi daya gentar yang sangat efektif, sedangkan dari seluruh instrumen itu yang dominan yaitu kekuatan militer yang fully loaded atau terisi penuh dengan kekuatan antariksa. Definisi operasi ofensif ini menguatkan kondisi struktur politik internasional yang telah diasumsikan oleh Mearsheimer ke dalam 5 (lima) asumsi utama.

Apabila melihat kepada kondisi alami strategis negara Indonesia maka perlu disadari kondisi keberadaan wilayah Indonesia di bumi ini. Sebagai negara yang memiliki kawasan perairan yang luas dan strategis, maka Indonesia saat ini berada dalam posisi berada ditengah atau dikelilingi oleh kutub-kutub kekuatan politik internasional baik dalam skala global maupun regional. Untuk itu konsekuensi logis yang harus ditanggung oleh Indonesia adalah bahwa keamanan wilayah laut dan wilayah dirgantara termasuk antariksa menduduki posisi vital pada tataran strategi pertahanan negara. Sehingga dalam kebijakan keamanan nasional, hal tersebut termasuk Ring I kebijakan keamanan nasional, yang meliputi Kebijakan pertahanan, kebijakan luar negeri, kebijakan ketertiban nasional, kebijakan politik nasional, dan kebijakan keamanan informasi dan telekomunikasi. Berbasiskan kondisi geografis kelautan ini maka kekuatan laut atau maritim yang dikuatkan dengan keantariksaan melahirkan geostrategi yang melekat bagaikan dua sisi keping mata uang, yaitu kekuatan antariksa dan maritim.

Melihat kepada perkembangan tekno-nasionalisme yang begitu agresif di kawasan regional hal ini menyebabkan Indonesia menjadi negara yang berada di kawasan geografis yang sangat strategis. Oleh sebab itu Indonesia memerlukan suatu politik luar negeri yang betul-betul mengedepankan pertimbangan pertahanan dan keamanan. Jika tidak terpenuhi maka Indonesia akan terancam kepentingan pertahanan dan keamanannya dari potensi gejolak yang muncul di kawasan sebagai akibat dari perkembangan tekno-nasionalisme tersebut. Sehingga perlu kemudian dilihat definisi Politik Luar Negeri. Politik Luar Negeri secara umum adalah suatu perangkat formula, nilai, sikap, arah, serta sasaran untuk mempertahankan, mengamankan, dan memajukan kepentingan nasional. Beranjak dari definisi itu, maka kegiatan antariksa khususnya aspek keamanannya tentu saja harus sejalan dengan pemahaman Politik Luar Negeri secara umum. Khususnya terkait dengan aspek keamanan yang menyangkut masalah mempertahankan, mengamankan, dan memajukan kepentingan nasional. Dimana keamanan bangsa dan negara Indonesia merupakan jantung dari kepentingan nasional Indonesia. Kemudian dengan kondisi sistem internasional yang anarki 
akan semakin mempertegas perlunya mengejar, meraih, mengamankan dan mempertahankan kepentingan nasional. Dalam konteks hubungan internasional sistem internasional dikatakan anarki bukan berarti adanya kekacauan, kurangnya aturan, atau tidak ada pola yang dapat dijadikan dasar dalam mengaturnya. Tetapi lebih kepada tidak adanya penguasa yang terpusat. Artinya, tidak ada otoritas tertinggi diatas kedaulatan negara. Maka sistem Internasional dalam interaksinya akan melibatkan banyak negara dengan tidak ada pemerintahan yang mengatur dari pemerintah-pemerintah negara berdaulat itu. Tentu saja ini membawa kon-sekuensi minimal bahwa kepercayaan negara-negara yang hidup dalam kondisi ini akan lemah dan menimbulkan keraguraguan dalam berinteraksi antara satu negara dengan negara lain.

Melihat kepada kebijakan Antariksa Indonesia dalam aspek keamanan yang dise-but dalam pasal 1 ayat 12 dan pasal 8 Undang-Undang No. 21 Tahun 2013 Tentang Keantariksaan pada hakekatnya harus menekankan kepada mengejar dan mempromosikan kepentingan nasional Indonesia di panggung antar negara-bangsa. Karena Antariksa merupakan batas kawasan baru yang dimanfaatkan sebagai bagian dari tujuan perjuangan abadi untuk memperoleh kekuatan dan kekuasaan yang sulit terelakkan. Sehingga jika suatu negara mampu mengembangkan kemampuan antariksa tentu akan semakin memperluas jangkauan negara hingga ke antariksa, dimana tujuan negara dalam memelihara kehidupan berbangsa dan bernegara akan dapat terwujud.

Dalam pasal 1 Ayat 12 tahun 2013 tentang keantariksaan, Keamanan dimaknakan sebagai segala upaya dan komitmen secara internasional bagi setiap Penyelenggara Keantariksaan untuk memelihara dan/atau menjamin pemanfaatan antariksa dan benda-benda langit lainnya untuk maksud-maksud damai dan tidak menimbulkan kerusakan bagi lingkungan bumi dan antariksa melalui keterpaduan pemanfaatan sumber daya manusia, fasilitas, dan prosedur. Selanjutnya di pasal 8 yang berisi kegiatan antariksa yang dilarang, dimana makna kegiatan yang dilarang tersebut sebenarnya mengandung kemampuan dan kepemilikan teknologi antariksa yang sangat tinggi, dimana Indonesia belum sampai pada tingkat tersebut. Dengan demikian maka secara normatif Indonesia akan dapat diterima oleh komunitas internasional karena dalam menterjemahkan pertahanan dan keamanan berbasis antariksa masih sangat lunak, dan kegiatan yang dilarang itu kemudian menjadi hambatan.

Tetapi dilihat dari perspektif realis ofensif ini merupakan satu hal yang kontradiktif dengan upaya pemenuhan rasa keamanan khususnya terkait pertahanan militer. Jika dikaitkan dengan pendapat Mearsheimer yang secara persuasif mengatakan bahwa dalam sistem 
internasional terdapat tiga hal, yaitu: (1) Tidak adanya otoritas sentral diatas negara yang mampu melindungi satu pihak dari pihak yang lain, (2) Kenyataan bahwa negara selalu memiliki kemampuan militer ofensif, (3) Fakta bahwa negara tidak pernah bisa yakin tentang niat negara lain dan kekuatan besar dipastikan tak henti-hentinya akan mengejar kekuasaan.

Kemudian sejalan dengan 5 (lima) asumsi realis ofensif oleh Mearshemeir, maka akan dapat dijelaskan sebagai berikut: pertama, keadaan anarkis dimana tidak ada pemerintah internasional yang berada di atas negara yang berdaulat. Untuk jaminan keamanan tentu saja tidak ada pihak manapun di dunia internasional yang memiliki otoritas mengatur pemerintahan negara berdaulat, termasuk pada konteks melihat suatu ancaman atau persepsi ancaman. Melihat kepada muatan pasal 8, dimana persepsi ancaman dimaknakan dengan kegiatan antariksa yang dilarang, tentu saja hal ini membawa konsekuensi politik bahwa Indonesia tidak diperbolehkan melakukan hal itu, tetapi esensi dari persepsi ancaman itu hendaknya diantisipasi dengan kesiapan teknologi yang mumpuni oleh Indonesia.

Kedua, tidak adanya keyakinan dari masing-masing negara atau pihak terhadap niat dari negara atau pihak lain. Asumsi ini sangat relevan dalam melihat kondisi dunia internasional terkini. Karena pengembangan teknologi yang bersifat strategis seperti teknologi antariksa pada awalnya dikonstruksikan sebagai upaya antisipasi terhadap ancaman keamanan dari negara atau pihak lain. Sehingga banyak negara-negara besar berlomba-lomba untuk membangun pertahanan dan keamanannya dengan berbasis keantariksaan. Sedangkan Indonesia masih jauh tertinggal.

Ketiga, keberlangsungan hidup suatu organisme negara menjadi motivasi utama yang harus diraih, sehingga keberadaan dari tujuantujuan yang ingin dicapai oleh negara tersebut dapat diwujudkan. Terkait dengan itu persepsi ancaman yang ditransformasikan kedalam muatan pasal 8 ini menjadi kontradiktif dengan perjuangan mewujudkan keberlangsungan hidup negara yang pada gilirannya menghambat dan mengancam pelaksanaan dan implementasi dari tujuan-tujuan dan nilai-nilai yang diyakini dan disepakati oleh seluruh komponen bangsa.

Keempat, negara sebagai entitas yang berpikir rasional untuk memaksimalkan tujuan dasar negara itu hidup dengan mempertimbangkan secara strategis lingkungan eksternal. Persepsi ancaman yang dibangun dalam muatan pasal 8 tersebut sejatinya mengandung muatan tingginya kemampuan teknologi antariksa yang telah dicapai suatu negara. Oleh sebab itu hendaknya Indonesia sebagai 
entitas yang berpikir rasional harus mengembangkan kemampuan keantariksaannya terlebih dahulu pada tataran atau tingkat tersebut, sebagai antisipasi terhadap lingkungan eksternal yang berkembang agresif dengan tekno-nasional-ismenya.

Kelima, melihat kepada dinamika internasional saat ini yang berbasiskan tekno-nasionalisme, maka setiap negara akan memiliki potensi untuk melakukan penyerangan dengan kemampuan militer yang dimiliki. Sehingga wajib dan perlu bagi Indonesia mengembangkan kemampuan antariksanya dengan maksimal untuk tujuan menghadapi dinamika tersebut.

Keamanan dan Pertahanan merupakan dua bidang yang bagi Indonesia sangat terikat atau tidak dapat bebas dari dinamika perubahan agresif yang terjadi di lingkungan tersebut. Oleh sebab itu sebagai sebuah tindakan yang antisipatif terhadap perubahan itu, maka negara dalam hal ini Indonesia haruslah melakukan tiga tindakan, yaitu: merumuskan, memutuskan dan melaksanakan program pembangunan di kedua bidang yang melibatkan keantariksaan. Tindakan-tindakan ini diambil oleh Indonesia dengan berdasarkan kepada kepentingan nasional yang tersirat dan inheren yaitu kelangsungan hidup. Terkait dengan kelangsungan hidup ini ditegaskan oleh Morgenthau bahwa syarat minimum yang harus dipenuhi oleh suatu negara adalah kemampuan untuk melindungi identitas fisik, politik dan budaya dari gangguan negara atau pihak lain.

Adapun bidang antariksa merupakan satu hal yang tidak dapat dipisahkan dari dinamika perubahan lingkungan yang agresif tersebut. Ini disebabkan karena antariksa merupakan teknologi strategis yang hendaknya menjadi bagian dari pemikiran atau kebijakan strategis. Sehingga tingkat agresivitas perubahan lingkungan strategis yang terjadi dimana aspek keamanan Indonesia harusnya mampu diperjuangkan dan dilindungi. Sebagai sebuah teknologi strategis maka pengembangan antariksa harus didayagunakan semaksimal mungkin. Hal ini tentu saja untuk mengantisipasi keguncangan-keguncangan yang timbul dari perubahan lingkungan baik yang berasal dari domestik atau khususnya dari internasional dan secara lebih signifikan adalah perubahan yang berdampak kepada aspek keamanan Indonesia. Seperti kasus penyadapan yang dilakukan pihak Amerika dan Australia dimana hal tersebut membuktikan lemahnya sistem keamanan nasional Indonesia di bidang teknologi informasi.

Kemudian Indonesia sebagai negara yang berdaulat hendaknya memiliki tugas untuk mempertahankan integritas wilayah Republik Indonesia terhadap tantangan, ancaman, gangguan dan hambatan baik yang datang dari dalam maupun dari luar negeri. Tugas ini apabila dikaitkan 
dengan perubahan lingkungan yang agresif tentu saja membutuhkan penajaman strategi yang merupakan bagian dari tindakan merumuskan, memutuskan dan melaksanakan program pembangunan di bidang keamanan dan pertahanan dengan mengedepankan antariksa sebagai perangkat utama. Kemampuan antariksa di dalam perjuangan mempertahankan integritas wilayah NKRI tidak dapat dibantah lagi di era globalisasi yang memiliki muatan ketidakpastian ini. Pengembangan dan penajaman strategi keamanan hendaknya didukung dan diwarnai oleh keantariksaan yang dikembangkan dengan sangat progresif, massif dan bebas dari kungkungan, baik teknis maupun psikologis. Dimana hal ini nampak dari muatan pasal 1 Ayat 12 Undang-Undang No. 21 Tahun 2013 Tentang Keantariksaan yang lunak dalam mendefinisikan keamanan, kemudian pasal 8 Undang-Undang No. 21 Tahun 2013 Tentang Keantariksaan yang melarang beberapa kegiatan antariksa yang sesungguhnya menjadi pembatas dalam pengembangan keantariksaan nasional, dimana hingga saat ini sesungguhnya Indonesia belum atau jauh menunjukkan kemajuan yang signifikan dalam keantariksaan.

Secara sederhana dapat dikatakan bahwa persepsi atau potensi ancaman seperti yang disinyalkan dalam pasal 8 jika dikonstruksikan ke dalam kondisi struktur politik internasional maka akan terbaca sebagai sebuah barrier atau hambatan bagi kemajuan Indonesia dalam mencapai teknologi itu sendiri, sementara di sisi lain Indonesia masih sangat jauh pencapaiannya. Sedangkan melihat kepada yang sudah dilakukan oleh negara maju pemilik teknologi seperti Amerika, maka akan terlihat hal itu tidak murni dipenuhi, melainkan menjadi subordinat dari kepentingan Amerika terhadap dunia global. Perilaku bertanggung jawab dan selalu memposisikan diri menjadi negara baik "good boy" merupakan hal yang bersifat naif yang sebenarnya merupakan hambatan yang diciptakan secara psikologis oleh masyarakat negara maju terhadap negara berkembang untuk membelenggu agar tidak secara agresif mengembangkan kemampuan antariksanya. Karena negara berkembang seperti Indonesia yang secara geopolitik adalah negara kepulauan dan memiliki banyak potensi konflik dengan negara tetanggga, seperti pelanggaran wilayah, klaim batas wilayah, penyadapan dan intervensi politik. Maka untuk mengatasi hal itu pengaplikasian satelit militer merupakan pilihan utama selain dapat mengantisipasi permasalahan tersebut, di sisi lain dapat juga menjadi efek penggentar bagi pihak atau negara lain yang ingin mengganggu. Seperti disadari bahwa kondisi terkini pertempuran adalah terlibatnya secara penuh teknologi informasi yang berbasis satelit atau cyber warfare.

Dari sisi pemikiran strategis, hendaknya muatan dalam pasal 1 ayat 12 dan pasal 8 Undang-Undang No. 21 Tahun 2013 Tentang Keantariksaan harus menunjukkan manifestasi dari kesiapan negara untuk mengatasi 
masalah-masalah baru di bidang keamanan negara. Dimana keamanan negara ini akan sangat dipengaruhi oleh perkembangan dan perubahan lingkungan strategis Indonesia yang masih akan berlangsung terus tanpa mengenal batas waktu dan kemungkinan dampaknya terhadap keamanan nasional. Pada konteks ini, Daoed Joesoef menyebutkan bahwa tuntutan yang harus dilakukan adalah upaya menerjemahkan perubahan menjadi sebuah prediksi dan kemudian menjadi sebuah tindakan. Muatan kedua Pasal tersebut hendaknya lebih ditujukan untuk aspek keamanan Indonesia dalam koridor keniscayaan ketidakpastian dalam sistem internasional, sehingga dapat dikatakan bahwa pemikiran strategis dalam muatan kedua pasal tersebut harus dapat berorientasi kepada keamanan Indonesia, harus mampu menjadi alat untuk mengantisipasi terhadap ancaman keamanan Indonesia, dan harus mampu membuat perkiraan-perkiraan akan ancaman yang ditujukan kepada Indonesia.

Sehingga muatan kedua pasal tersebut hendaknya mencerminkan kebutuhan Indonesia akan sebuah teknologi strategis yang mampu di dayagunakan sebagai bagian dari strategi keamanan nasional Indonesia secara komprehensif. Adapun teknologi strategis yang harus di bangun, dikembangkan dan diaplikasikan adalah satelit militer dan roket peluncur satelit yang sebenarnya adalah roket balistik.

Dalam pandangan realis ofensif, Aspek kegiatan keamanan Antariksa yang disebut dalam pasal 1 Ayat 12 dan pasal 8 Undang-Undang No. 21 Tahun 2013 Tentang Keantariksaan masih sangat mengedepankan keberadaan Indonesia sebagai "good boy" dalam struktur dan sistem internasional. Hal ini sangat kontraproduktif dengan tindakan menjaga integritas keutuhan wilayah NKRI, karena untuk menjaga itu diperlukan suatu keamanan yang maksimum di satu sisi, sedangkan sisi yang lain jelas bahwa keamanan menurut realis ofensif merupakan suatu hal yang sangat langka dalam sistem internasional. Oleh sebab itu pengembangan antariksa haruslah bersifat agresif, progresif dan masif sehingga akan mampu memenuhi keamanan negara sebagai wujud dari kepentingan nasional memperjuangkan kelangsungan hidup atau "survival". Selanjutnya jika suatu negara menginginkan untuk dapat bertahan hidup di era antariksa maka harus melakukan pembangunan dan pengembangan kemampuan antariksa secara maksimal tanpa terbelenggu oleh pemikiran menjadi negara yang baik atau "good boy". Sehingga dengan demikian maka prestise dan kewibawaan Republik Indonesia akan semakin bertambah, dan pada gilirannya Indonesia menjadi negara berdaulat yang utuh karena memiliki daya gentar bagi negara lain. 


\section{Simpulan}

Dari pemaparan tulisan tersebut di atas, secara sederhana dapat dikatakan bahwa perkembangan kegiatan antariksa hari ini semakin progresif dan masif. Tentu saja menjadi suatu keharusan bagi suatu negara untuk mengembangkan dan memiliki teknologi antariksa, dimana hal itu harus dilakukan dengan progresif dan masif pula. Hal ini dikarenakan kemampuan dan aplikasi yang dimiliki oleh teknologi antariksa sangatlah luas. Bidang yang menduduki posisi prioritas utama yang sangat membutuhkan adalah berkenaan dengan bidang keamanan dan pertahanan, khususnya militer. Penerapan teknologi ini sangatlah signifikan di bidang keamanan dan pertahanan suatu negara. Banyak negara besar seperti Amerika dan China misalnya yang sangat progresif dan masif mengembangkan serta memilikinya.

Konsekuensi logisnya adalah suatu negara akan memacu pengembangan dan kepemilikan teknologi ini hingga tidak terbatas. Hal tersebut terbukti dengan pandangan dari Amerika maupun China dalam membangun keantariksaannya, yaitu bahwa antariksa memiliki nilai strategis yang sangat tinggi. Oleh sebab itu apabila dikaitkan dengan pendekatan realis ofensif, maka kita akan melihat bahwa ketidakpastian keamanan pada struktur dan sistem internasional yang dihadapi oleh Indonesia hendaknya menjadi fundamental utama pengembangan dan pemilikan kemampuan antariksa ini. Mengingat Indonesia saat ini telah mendapatkan serangan ancaman melalui teknologi berbasis antariksa seperti satelit mata-mata, maka segala bentuk hambatan atau halangan yang muncul bagi pengembangan strategis keantariksaan harus dihadapi dengan progresif. Maka hendaknya materi dalam pasal 1 Ayat 12 dan pasal 8 Undang-Undang No. 21 Tahun 2013 Tentang Keantariksaan dapat lebih progresif dan mencerminkan ketegasan kebutuhan keamanan negara Indonesia. Karena sesungghuhnya kemampuan Indonesia dalam pengembangan keantariksaannya masih jauh dari tingkatan kegiatan antariksa yang dilarang tersebut.

\section{Daftar Pustaka}

\section{Buku dan Artikel dalam Buku}

Bandoro, Bantarto, 2014. Indonesia dalam Lingkungan Strategis yang Berubah. Graha Ilmu. Yogyakarta.

Djafar, Zainuddin \& Robby Aulia Fadila, 2013. Menuju Peran Strategis Indonesia Di Lingkungan Regional dan Global.Politik Luar Negeri Indonesia Di ba-wah Pemerintahan Susilo Bambang Yudhoyono. Bandung: Pustaka Jaya. 
Donnelly, Jack, 2000. Realism and International Relation. Cambridge. University Press.

Hara, Abubakar Eby, 2011. Pengantar Analisis Politik Luar Negeri Dari Realisme sampai Konstruktivisme. Nuansa. Bandung.

Hollis, Martin And Steve Smith, 1990. Explaining And Understanding Internati-onal Relations. Clarendon Press. Oxford.

Joesoef, Daoed. 1991. Renungan Tentang Studi Strategi dan Hubungan Interna-sional di CSIS. Jakarta.

2014. Studi Strategi. Logika Ketahanan dan Pembangunan Nasional. Kompas Media Nusantara. Jakarta.

Mearsheimer, J.J, 2007. "Structural Realism", dalam T. Dunne, M. Kurki \& S.Smith (eds.), International Relations Theorise: Discipline and Diversity. Oxford: Oxford University Press.

Mearsheimer, John J., 2001. The Tragedy of Great Power Politics. New York: Norton.

Morgenthau, Hans J., 1973. Politics Among Nations. The Struggle for Power and Peace. New York:Alfred A. Knopf Inc.

Nugroho, Riant, 2013. National Security Policy. Sebuah Pengantar. Pustaka Pelajar. Yogyakarta.

Undang-Undang Republik Indonesia Nomor 21 Tahun 2013 Tentang Keantarik-saan.

\section{Artikel Jurnal}

Adams, Karen Ruth, 2003. "Attack and Conquer? Ainternational Anarchy and the Offense-Defense-Deterrence Balance." International Security 28 (3): 45 .

Frankel, B., 1996. "Restating the Realist Case: An Introduction", Security Studies 5 (3): 9-20.

Granoff, Jonathan and Craig Eisendrath, 2005. United States-Masters of Space?, The US Space Command's "Vision for 2020". Global Security Institute.

Muhibat, Shafiah F., 2013. "Pergeseran Kekuatan di Asia Timur dan Konsekuensi bagi ASEAN: Persepsi Ancaman dan Kerja Sama Keamanan Regional." Analisis CSIS 42 (3).

Rousseau, David L. dan Rocio Garcia-Retamero, 2007. "Identity, Power, and Thre-at Perception A Cross-National Experimental Study." Journal of Conflict Resolution 51 (5).

\section{Artikel Online}

Chase, Michael S. 2011. Defense and Deterrence in China's Military Space Stra-tegy. Publication: China Brief 11 (5) [online] dalam http://www.jamestown.org/programs/chinabrief/single/ 
Defense, 2011. National Security Space Strategy Unclassified Summary. [online] dalam http://www.defense.gov/home/features/2011/o111_nsss/docs/Natio nalSecurity SpaceStrategyUnclassifiedSummary_Jan2011.pdf

The Environmental Anarchy.

http://faculty.washington.edu/caporaso/courses/203/notes/w1paradig ms_of_ir.html.

Finch, James P., 2011. Finding Space in Deterrence Toward a General Frame-work for "Space Deterrence". Director Shawn Steene, Deputy Director Space Policy and Strategy Development Office of the Undersecretary of Defense for Policy. Strategic Studies Quarterly. Winter[online] www.au.af.mil/au/ssq/2011/winter/finchsteene.pdf.

Hans Günter Brauch, 2011. Concepts of Security Threats, Challenges, Vulnerabi-lities and Risks [online] dalam www.springer.com/.../9783642177750-c1.pdf

Pike, John, 1998. American Control of Outer Space in the Third Millennium [online] dalam http://www.fas.org/spp/eprint/space9811.html

Rear Admiral Simon Williams OBE, 2012. The Role of the National Interest in the National Security Debate. [online] dalam www.da.mod.uk/.../SHP-2012-Williams.pdf

The Butcher, 2015. Pentagon Rushing to Open Space-War Center To Counter China, Russia. [online] dalam http: /punditfromanotherplanet.com/2015/o6/24/pentagon-rushing-toopen-space-war-center-to-counter-china-russia

Toft, Peter, 2005. "John J. Mearshemeir: An Offensive Realist Between Geopolitics And Power." Journal Of International Relations and Development. 8 (4) [online] dalam http://www.palgravejournals.com/jird/journal/v8/n4/full/1800o65a.html.

Wedler, Carey. 2015. The Final Frontier: US Building War Command Center to Take Foreign Policy to Space [online] dalam http://theantimedia.org/pentagon-buildingwarcentermachineapparatus-space

Xuetong, Yan, 2011. From a Unipolar to a Bipolar Superpower System: The Futu-re of the Global Power Dynamic [online] dalam http://carnegie tsinghua.org/2011/12/30/from-unipolar-to-bipolarsuperpower-system-future-of-global-power-dynamic 